\title{
How has Botanical Illustration influenced Surface Pattern Design?
}

\author{
Bethany Morgan, University of Huddersfield
}

B.Morgan@hud.ac.uk

Accepted date: 08/11/2017

Published date: 21/02/2018

\begin{abstract}
Botanical illustration has been a key feature throughout history, developing from scientific aid to one of the most universally recognised decorative motifs. Its transition into surface pattern design is most recognisable in the nineteenth century with the emergence of William Morris's wallpapers, and it has formed an ever-changing influence on modern-day design.
\end{abstract}

This article discusses the humble beginnings of botanical illustration, starting out in the cave paintings of prehistoric humans. It then tracks the changing uses and meaning through history, reaching the modern day, where it will discuss botanical illustration's impact on key figures in the fashion industry. The article will also include discussion of the popularity of flowers and research conducted into the emotional impact of depicted florals - touching on the biophilia hypothesis - serving to highlight the continuing importance to humans of florals in any form.

\section{Keywords}

Botanical illustration, surface pattern, florals, William Morris, design, fashion 


\section{Acknowledgements}

Thanks are expressed to the participants who contributed to the study. A special thank you to my supervisor, Katy Suggitt, for endless amounts of encouragement, guidance and support. Further thanks are due to my tutors, Graham Lister and Dale Holmes, for pushing me to achieve the best I could in my practice-based research. 


\section{Introduction}

Botanical illustration was born out of the human desire to learn and understand more about the surrounding world. Since the earliest civilisations, plants have been depicted in many different forms, from decorative art on pottery to stone relief (Knapp, Raven, Raven, \& Magee, 2003). With the slow advance of science, botanical illustration became a tool with which to gain knowledge and understanding of the natural world.

The seventeenth century saw a growth in public appreciation and interest in flowers due to an increase in imports of plants from voyages overseas (Knapp et al., 2003), resulting in botanical illustration beginning to take the form of a scientific aid and a recognised decorative design. Since the seventeenth century, botanical illustration as decoration has become ubiquitous in design, most notably with the emergence of William Morris wallpapers in the nineteenth century, and is now recognised as one of the 'most universally popular of all decorative motifs' (Abrahams, 2009, p. 82).

Previous research undertaken into this subject has generated new and interesting knowledge which this study intends to bring together to explore specific questions about the influence botanical illustration has had on surface pattern design, especially contemporary design. The fashion industry has played an important role in the current influx of florals, and it is the aim of this article to explore this in relation to botanical illustration.

This article will begin by tracking the changing uses of botanical illustration through time, placing it within a historical context to analyse its transition into surface pattern design. Following this there is discussion and analysis of findings from an online survey about the popularity of flowers, establishing 
whether there is a deeper relationship between florals and humans. By studying key figures that prompted the movement from scientific aid to prominent well-known design, focusing on specific pieces and collections by William Morris and select contemporary fashion designers, the article will then explore themes within their work that are evident through history - such as the symbolism of florals - and will bring together all findings to provide a further understanding of the connections humans have with the natural world.

\section{Botanical illustration: a history}

It can be argued that botanical illustration has been an important feature in the development of humankind due to its presence throughout the course of history. According to Knapp et al. (2003), artistic representations of flowers are some of our most ancient images and have been found within cave paintings of prehistoric humans. The drawings unearthed within a cave in Tennessee's Cumberland Plateau are believed to represent the Native Americans' prehistoric world within three dimensions: drawings at the top of the cave represent religious beliefs, the middle sections 'usually show plants, animals and the world in which they would have lived' (Woollaston, 2013) and finally, the lower section represents darkness, death and danger. There are numerous theories on what cave drawings represent. One theory suggests they were a means of communication and another that they have 'a religious or ceremonial purpose' (Cave Painting, 2017). The concept of symbolism within cave paintings contradicts Knapp et al.'s (2003) idea of floral imagery being used solely as decoration. Plants within cave paintings were a small part of a larger interpretation of the world that prehistoric humans inhabited. 
The real starting point for plants being the main subject of illustrations was the creation of the first 'herbal' by the ancient Greeks. A herbal is a book containing information about plants with medicinal qualities. The ancient Greeks were the first civilisation to start to discover the healing qualities of certain plants and began cataloguing them, accompanying the text with an illustration of the described plant. The 'rather stiff and unnatural illustrations' (Knapp et al., 2003, p. 13) contained within these herbals were referenced by Pliny the Elder, who was a Greek naturalist, author and philosopher, in the first century BC (Saunders, 1995). They were only placed into the herbals as a decoration to accompany the text rather than as a classified piece of scientific documentation. The earliest printed herbals were a product of a culture that repeated received wisdom rather than analysing and exploring for new information (Saunders, 1995). The illustrations within this time period reflected this; without geographic exploration, botanical illustration would not have developed such a significant role.

As science started to develop, botanical illustration began to be recognised as a real aid to the scientific world as a means of documenting and recording specimens. During the sixteenth century and up until the early seventeenth century, it is suggested that plants were still established as no more than sources of food and medicine, which indicates that perhaps the botanical illustrations being produced were slightly more developed than the herbals of ancient Greece. However, thinking back to the earlier discussion of the possible symbolism of plants within the cave paintings of prehistoric humans, other potential interpretations at this time are possible. In the late sixteenth century, botany was established as a separate scientific discipline from 
medicine in Europe (Saunders, 1995), and came into being due to the arrival of new species of plants from different countries and the new approach to science that focused upon exploration, experimentation and observation. This new take on science had a major impact on the botanical illustration of the time, as the images started to become more vital to the text when describing species of plants. 'The purpose of Botanical Illustration is to further the understanding of the science, to provide the botanist, physician and gardener with an aid to identification' (Knapp et al., 2003, p. 12.). Providing an aid to identification highlights the change in both the use and importance of botanical illustration within that era. Ensuring a detailed description is accompanied by an accurate illustration makes sure no mistakes are made when classifying a plant, thus reducing the risk of the misidentification of a toxic specimen. Prior to the depiction of plants for scientific purposes, the only means of identification was a dried specimen (Knapp et al., 2003). This, again, emphasises the need for botanical illustration within the field of science, although botanical science dictated the ways in which artists represented specimens by stating what should be included to ease the identification and classification. The two different types of botanical illustration, according to Saunders (2003), were 'illusionistic pictorial representation' (normally coloured illustrations) and 'outline schematic representation' (normally black and white, and useful for the analysis of plant morphology). This restriction produced illustrations slightly devoid of individual creative qualities, which perhaps was a factor in the creation of the florilegium and the pattern book. 
The seventeenth century became the era in which plants started to be grown for their decorative qualities, colours and forms rather than their medicinal properties. This influenced the creation of the 'florilegium', which literally meant a book filled with flowers (Saunders, 1995). Illustrations within a florilegium had no scientific purpose, intent to classify or explore the subject, but were a statement of possession and ownership for the wealthy. An example of such documentation of wealthy ownership is Basilius Besler's Hortus Eystettensis (1613). Commissioned through the desire to record for posterity the garden of Eichstätt by John Konrad von Gemmingen, the Prince Bishop of Eichstätt, it contained a large collection of illustrations that documented most of the plants within the garden, including Red Pepper Plants (Besler, 1613). The interesting aspect of this particular florilegium is that two versions were printed, one in black and white with text, which was aimed at apothecaries as a reference book, and another, classed as the 'luxury' version, without text but with coloured illustrations (The British Library, 2005). This suggests that during this period of time, botanical illustration had started to split into two categories aimed at different audiences who would interpret the images they saw differently. The coloured copy of Hortus Eystettensis was considerably more expensive than its black and white counterpart, resulting in the florilegium really only being available to the wealthy in society. It was in 1787 that The Botanical Magazine (also known as Curtis's Botanical Magazine) was founded by William Curtis, which that meant less affluent households could afford to own botanical illustrations (Knapp et al., 2003). This movement into publication for enjoyment rather than as a statement of ownership, and transition away from using it solely as a scientific 
medium, could be said to link with the gradual emergence of floral imagery being used as decoration. The new varieties of plants that were available due to sailors, traders, naturalists and collectors returning from voyages overseas also gave a broader range of subjects for both the scientific botanical illustration and the more artistic botanical illustration to capture.

As well as the florilegium emerging as a record of a garden, the pattern book was also created. This served more as a guide for artists and designers to recreate the floral imagery in a chosen art form rather than as a means of cataloguing or scientific analysis. Some of the pattern books actually stated the audience they were aimed at, for example painters, embroiderers and weavers, and within the accompanying text gave details of the colours of the flowers to ensure the artist could create an accurate representation (Saunders, 1995). The composition of a pattern book focused more on the aesthetics rather than the types of plants themselves, which is a very strong indication that botanical illustration was really starting to move away from science, giving way to the illustrations having a higher degree of pictorial naturalism for beauty rather than detail. While still being used as a tool for science, this new creative take on botanical illustration would, perhaps, be more widely recognised with the emergence of William Morris's work in the nineteenth century, which will be discussed in more depth later in this article.

Kew Gardens, which was established in the eighteenth century when Captain Cook was travelling the world and bringing back specimens, has played a prominent part in the history and rise of botanical illustrations. Joseph Banks, a naturalist and a future director of Kew Gardens, accompanied Cook on his voyages and took two artists with him to record the natural history and 
geography of those voyages (Stearn, 1990). When Banks became director of Kew, he sent collectors abroad to collect and introduce new plants into the garden which is why, now, ' $90 \%$ of all known species are represented in one way or another' at Kew (Page \& Geffen, 2012). It could be said that this rapid influx of new species into Kew was the reason botanical illustration became such a massive means of documentation for both a scientific and an aesthetic purpose. Franz and Ferdinand Bauer are regarded as two of the greatest botanical artists because their work captured the essence of the organism and was most scientifically accurate (Knapp et al., 2003), but their illustrations also stand as 'aesthetic masterpieces timeless in their quality' (Stearn, 1990). Banks hired Franz Bauer to become one of the botanical artists at Kew, where he became an expert microscopist, meaning he was able to portray plants in exquisite detail (Stearn, 1990). The Bauer brothers' work could be argued to balance art and science. Being recognised within the scientific world for the accuracy but also in the artistic world for the skill and aesthetic qualities gives an indication of the way botanical illustration can transition between the two elements with ease. According to Saunders (1995, p. 12.), 'photography has never suspended drawing in the field of botanical illustration'; this is perhaps due to an artist being able to capture and combine elements of a specimen in one illustration 'with greater economy and precision' (Saunders, 1995, p. 12) than a photograph or the physical specimen could.

Botanical illustration is still present today; however, its uses have altered from those in the seventeenth and eighteenth centuries. Documentation of plants in a scientific way is now done through the manipulation of technology, which 'gives an insight into plants in a way that we've never had before' (Page \& 
Geffen, 2012). The main focus of scientific botanical illustration in the present day is to discover aspects of plants that are not usually available to the human eye rather than cataloguing new species of plant. Moving on from florilegia and pattern books, botanical illustration can, at present, be found everywhere from household items to clothing.

\section{Research methods}

At this stage, the article has tracked the historical beginnings of botanical illustration, analysing the changing uses and meaning of florals through the centuries to the modern day, when florals are used to adorn many different items within today's society. To start to begin to understand the deeper relationship between humans and florals, quantitative research needed to be explored. Important questions to consider when contemplating how botanical illustration has influenced surface pattern design are why are flowers considered to be so 'universally popular', and why do people choose to adorn their homes, bodies and businesses with botanical imagery? Conducting a survey of 77 people gave a greater understanding of the reasons why the public choose to purchase items of a botanical nature. Structuring the survey into both multiple choice and written questionnaire sections allowed for numerical statistics and opinions to be collated and analysed.

The age range of the participants was from 18 to 64 , and the 70 women and 7 men completed an online survey. Of the 77 participants, 71 claimed to own something botanically influenced, with the highest number aged between 18 and 24; however, it was clear that the popularity of botanical prints is apparent in all of the age groups surveyed. This could be for many reasons, so required a more in-depth questionnaire section to gain an understanding of the true 
reasons why these participants bought these items. As most of the participants were female, a further survey of a larger number of people with equal numbers of male and female participants would gain a more accurate insight into the popularity of botanical items among the different age groups.

\section{Findings - the popularity of florals}

When participants were asked, 'why do you think items depicting nature/flora are appealing?' within the written section of the survey, a recurring response was that it allows nature to be brought into the home when living in an urban environment so that those who cannot access nature directly still have the opportunity to interact with it. A number of comments suggested that florals prompt specific memories, with one participant saying that florals 'remind [them] of [their] grandma's pressed flower arrangements'. Positivity was a key word mentioned a number of times throughout the survey. Thinking of florals as an image of positivity starts to suggest that perhaps the human connection with nature is not just on an aesthetic level, but is a more complex, emotional relationship. The link between flowers and emotion is something well known within society; however, as the survey was conducted about items depicting florals rather than physical florals themselves, it is clear that the same emotional connections may apply whether it is a depicted floral or a real flower. This could suggest the reason why floral designs are so popular.

To gain further understanding of the link between humans and depicted florals, a question in the survey - if the participant had stated they owned something botanically influenced - was to select which items they owned. Table 1 shows the percentages of participants who own items in each category, with an average of $25 \%$ of participants selecting that they own 
items in multiple categories. 'Clothing' was shown to be the most popular category, with $73 \%$ of participants, followed by 'Home Accessories', with $60 \%$. The idea of floral fashion being the most popular category, in a sense, relates back to the idea of flowers representing positivity. Adorning the body with floral imagery through clothing could prompt increased self-confidence and could suggest why fashion designers such as Alexander McQueen and Christopher Kane are utilising florals within their collections. Within the $8 \%$ who selected 'Other' was a participant who stated they had a botanical tattoo; this is a clearer statement of the individual's personal relationship with nature.

\section{Table 1}

Statistics from survey

\begin{tabular}{|l|c|}
\hline Item & Percentage of Participants (\%) \\
\hline Clothing & 73 \\
\hline $\begin{array}{l}\text { Interior Decoration (e.g. wallpaper, } \\
\text { furniture, fabrics) }\end{array}$ & 44 \\
\hline $\begin{array}{l}\text { Home Accessories (e.g. cushions, } \\
\text { vases, ornaments) }\end{array}$ & 60 \\
\hline Stationery & 26 \\
\hline Other & 8 \\
\hline
\end{tabular}

The large number of participants who own items depicting florals could suggest the concept of utilising florals as a means of making nature more accessible within urban living, and it would be interesting to explore the correlation between living environment and depicted florals being used as décor in the home. The idea of florals being a connection to emotion and memory relates to the biophilia hypothesis, which will be discussed later in the 
article. This survey has given new insight into how humans interact with not only florals, but the image of florals, and the ways in which people react and interact with flowers.

\section{Botanical illustration as surface pattern design}

William Morris's work, even to this day, is one of the most recognisable forms of botanical illustration within design. His work, discussed as 'a flowing, intense evocation of the natural world, described with clarity and skill' by Wilhide (1991, p.10), gives a sense of the ways in which Morris captured his subject and could also suggest the emotional reaction the designs prompt. Within his wallpaper designs, he chose to use plants native to Britain, which was unusual in the 1860s, as prior to this the only acceptable floral decoration for the home was brightly coloured, exotic, imported blooms (Parry, 2009). The somewhat controversial use of native plants within his designs was, perhaps, Morris's way of documenting the overlooked species, highlighting the idea of these plants being freely available to influence all, unlike the expensive imported blooms which would usually be situated within a wealthy owner's garden. Each of his wallpapers is named after either flora or fauna (Parry et al., 1996), an example being his piece Tulip (Morris, 1919). Like many other designs, Tulip captures the essence of the plant, unlike the overly detailed naturalistic wallpapers of the nineteenth century, which were actually unsuccessful at depicting the flowers in a realistic way (Victoria \& Albert Museum, 2006). Perhaps the use of plants as names for the wallpaper links back to the cataloguing of specimens within botanical illustration and, in essence, Morris was using his designs as a means of cataloguing the plants he depicted. Within traditional botanical illustration, the techniques for 
reproducing the illustrations were wood block printing and eventually etching; this allowed artists to incorporate great detail within their designs. 'Morris insisted on learning how things were made, selecting old manufacturing techniques' (Parry, 2009 p. 4); one of those techniques was wood block printing. Traditional botanical illustration was a major influence on Morris in the creation of his wallpapers, not only with the subject matter but also with the actual physical means of realising the design.

The Arts and Crafts movement is a design movement born out of the concern for how industrialisation was affecting design, traditional skills and the lives of normal people (Victoria \& Albert Museum, 2005). Morris, who was 'often called the father of the Arts and Crafts Movement' (Goodman \& Collins, 2013), was one of the two most influential figures, the other being John Ruskin. Ruskin was not actually part of the Arts and Crafts movement; however, it was his writings that inspired the core values on which the movement was founded. Rejecting the Utilitarian society he lived in, Ruskin 'believed that the essential relationship was between [hu]man[s] and nature, and that the medium of this relationship was work' (Hewison, 1976, p. 137). This strong sense of process bringing humans closer to nature is evident in Morris's work, but the depiction of the natural world in other works created within the movement also reflects this value. It could be argued that the link between plant, artist and process within traditional botanical illustration was an influence on Ruskin, as creating the illustrations took skilled craftspeople, something that Ruskin - and the Arts and Crafts movement - was fighting to save. According to Hewison (1976, p. 136), industrialisation causes humans to be 'alienated from nature'. Today, with an ever-growing population, it could 
be said that as a society this alienation from nature is occurring due to the very issues Ruskin described. Mass production is a prominent part of the modern world; from buildings to fashion, it is very difficult to find something that has not been created by a machine.

In the Art League's blog post What is Surface Design? It's All Around You (2015), the term 'surface pattern design' is defined as encompassing 'the coloring, patterning, and structuring of fiber and fabric'. There is not one clear definition; however, it could be argued that the main concept is the manipulation of the surface of materials. An alternative view from surface pattern designer Renata Rubim suggests the term 'is used to define all projects made by a designer, in respect to the graphic treatment and colour used on a certain surface, industrial or not' (Noaleco, 2009), and member of the Surface Design Association Evelise Rüthschilling defines it as 'a technical, creative activity that aims to create bi-dimensional images (visual and tactile textures), projected specifically for the constitution and/or treatment of surfaces, presenting aesthetic and functional solutions to the different materials and processes of industrial and handicraft productions' (Noaleco, 2009). This suggests that the term 'surface pattern design' alters depending on the context in which it is being used. As previously discussed, William Morris's work is a clear example of the representation of florals within surface pattern design upon paper and fabrics. When thinking about how botanical illustration has influenced surface pattern design - as well as looking at William Morris - the fashion industry is an important element to be explored due to the increasing numbers of designers utilising florals within their 
collections. A key question to be considered is, how does the representation of florals within fashion differ from that of botanical illustration?

Dolce \& Gabbana (2016) released their Autumn/ Winter collection featuring bold floral prints and delicate botanical embroidery to reflect the theme of fairy tales. The use of florals, within a collection whose main inspiration was the fictional, contrasts with traditional scientific botanical illustration and starts to align itself more with the symbolism seen in literature and Pre-Raphaelite paintings than that in academia. This perhaps highlights the changing relationship between humans and the natural world, giving the use of florals a whole new life within surface pattern design. An important example of botanicals portraying a deeper meaning is Alexander McQueen's Sarabande collection (2006), being influenced by Handel's Sarabande (an elegant dance), Goya and Marchesta Luisa Casati (Yukikoandthe, 2012), but also English Gardens (Naturalism, 2010). The collection heavily featured florals trapped within delicate chiffon, giving garments a melancholic undertone. Upon witnessing a section of this collection first hand during McQueen's Savage Beauty exhibition (2015), it was evident that McQueen's intention was to use florals as a metaphor for death. A dress embroidered with hundreds of both silk and fresh flowers that shed as the model walked down the catwalk is perhaps one of the most iconic garments from this collection and, when seen in person, it could be argued to be the most successful at reflecting McQueen's concept of the 'inherent beauty found in death and decay' and 'the transient nature of life' (Naturalism, 2010). Due to the placement of the flowers, there is perhaps a sense of metamorphosis within the garment; the model is being encased by an array of flowers that, in a sense, could link with 
McQueen's overall concept of transience. There is a long history of symbolism within garments, which McQueen might have considered when creating this collection, with wedding dresses possibly being one of the most well-known symbolic garments. 'Brides choose a dress of white to symbolise purity of the soul' (History of Wedding Dresses, 2013). The combination of using flowers as a symbol for death and the physical garment perhaps being a symbol for purity of the soul moves McQueen's work drastically away from scientific botanical illustration and into its own category of complex, symbolic floral representation.

In complete contrast to McQueen's symbolic Sarabande collection (2006) is Christopher Kane's Spring/Summer 2014 Ready-to-Wear collection (2013), which featured 'bookish illustrations of botanicals' that were 'the kind you study in science class' (Harris, 2013). This more scientific approach to depicting florals could be the clearest aesthetic link to the botanical illustration of the past within fashion. Although the sliced flower illustrations on skirts and jumpers are more modern and graphic than traditional botanical illustration, it could still be said that within this collection, Kane is trying to highlight the close connection between botanical art and botanical science. Inspired by the process of photosynthesis (Blanks, 2013), the illustrations on the garments are depicting and documenting a flower's reproductive system; this is Kane commenting on how flowers and trees release oxygen, which sustains life, but humans take advantage of this. This collection also emphasises the equivalence of the female anatomy to a flower' (Blanks, 2013). Kane's collection could be seen as almost humorous due to the insinuation of the female anatomy contrasting with a very conservative-style garment. Making 
connections between flowers symbolising the human anatomy could be compared with McQueen's use of flowers to symbolise death. The deeper meaning within Kane's collection could be argued to represent the modernday relationship society has with the natural world and, now that botanical illustration is not required to document new species, flowers are allowed to represent more than just scientific facts and evolve into something altogether more complex.

Wilcox explains that 'nature provided endless stimulation to [McQueen's] creative talents' (2015, p.123), and it is clear that this statement can be applied to many different designers. The exhibition Fashion \& Gardens at the Garden Museum (2014) brought together the works of many fashion designers, McQueen included, who have taken direct influence from gardens, as well as collections of traditional botanical illustrations. Bringing together all of these different elements gives a sense of how even something as small as a garden can be a major influence, but also how connected humans are to the natural world, whether that be depicting it through illustration or using natural products to make things. The current sudden influx of florals within fashion, as well as other aspects of design, could be linked with the issue of growing population and mass production discussed earlier. Green belt land in the UK covers $13 \%$ of the country; in the past five years, building on this land has drastically risen (Urry, 2015), suggesting that fewer people are being exposed to the natural world. The idea of nature prompting emotional reactions and having a connection with memory discovered within the previously discussed survey perhaps links with the biophilia hypothesis - the 'idea that humans possess an innate tendency to seek connections with nature and other forms 
of life' (Rogers, 2016). Ulrich states 'that exposure to nature fosters psychological wellbeing, reduces the stress of urban living and promotes physical health' (1993, p. 74). This could explain the rise in the depiction of florals, as it could be said the images of the florals are promoting the same effects on psychological wellbeing as physical nature. Depicted florals is also, perhaps, a way in which society can once again become linked with nature, and contrasts with bleak city life. Looking back to the Arts and Crafts movement, the botanical-inspired prints of today could be trying to counteract humans being 'alienated from nature' (Hewison, 1976, p. 136) and bring back a sense of the natural world, but could also be highlighting its importance to humans, in an increasingly industrialised nation.

To explore further this concept of the human connection with depicted florals, I undertook practice-based research into the subject. Through the physical act of painting, it became a process of documentation and exploration. Utilising images taken at first hand on a visit to the Royal Botanic Gardens at Kew, I began to consider how these physical florals could be transformed into paintings.

Thinking further about the plants that were used as sources for the practical research, it became apparent that they are all found within the confines of the greenhouses at Kew Gardens. The exotic nature of the plants requires them to be grown within an artificially created climate, as they would not survive in the typical UK environment. Figure 1 shows a site-specific piece that was created in response to these factors. As this series of paintings are specific to the place in which they are painted, this could be said to be a way of documenting the fact that the plants depicted are only able to survive within a 
certain space: the work exists in the confines of similar space to that of the flowers. As Figure 1 is an installation that allows a person to be immersed within the florals, a considerable number of people gave an emotional response after being within the work, with many stating the experience made them feel 'positive' and 'happy', and someone actually asking if I 'could come and paint this in [their] house'. This practical research further confirms the emotional connection to nature previously discussed within the online survey and adds to the knowledge of exposure to natural imagery 'fostering psychological wellbeing' (Ulrich, 1993, p. 74).

\section{Figure 1}

Site-specific work

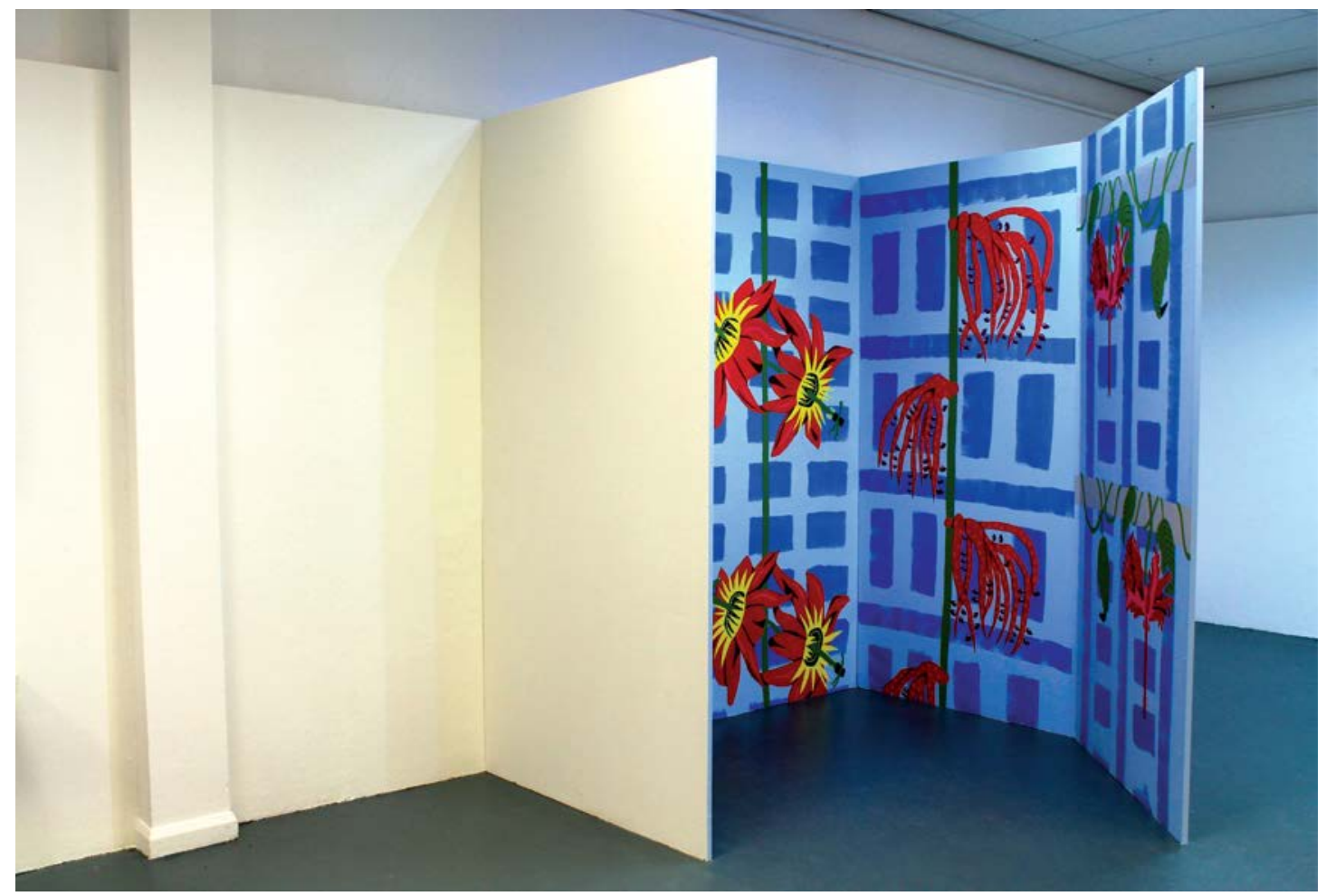

\section{Conclusion}

From detailed research into many aspects of botanical illustration, a number of conclusions can be drawn. Firstly, it was interesting to analyse how 
botanical illustration developed, from the inclusion of plants in symbolic cave paintings to the present day, where florals are still being used symbolically as well as decoratively, with Alexander McQueen's Sarabande (2006) collection being a clear example of this. The changing uses tracked through history show that botanical illustrations have been, and always will be, needed in some form. Science has advanced enough to no longer need illustrations to document specimens, but, as an art, society has expressed its need to document plants in the form of surface pattern design to ensure they are captured forever. From this it can be concluded that, due to the increasingly industrial landscape of the modern age, the use of florals within surface pattern design is a way of bringing people back to nature. Finally, the results of the survey undertaken, along with the practice-based research conducted, all show a strong emotional attachment to florals, in some cases prompting certain memories in some participants. This could explain the popularity of florals as surface pattern design, highlighting the idea that the human relationship with flowers is more than just to do with aesthetics. Due to the detail of the research, one can conclude that the relationship between humans and the natural world is ever changing, but the presence of nature in the designs made is omnipresent, and it can be argued that nature will always be an influence on humankind. 


\section{References}

Abrahams, C. (2009). Wallpaper: The Ultimate Guide. London: Quadrille.

Besler, B. (1613). Hortus Eystettensis. Retrieved from http://www.bl.uk/collection-items/hortus-eystettensis

Blanks, T. (2013, September 16). Christopher Kane Spring 2014 Ready-toWear Collection. British Vogue. Retrieved from http://www.vogue.com/fashion-shows/spring-2014-ready-towear/christopher-kane

Cave Painting (2017, January 9). Retrieved from Wikipedia: https://en.wikipedia.org/wiki/Cave_painting\#Theories_and_interpretatio ns

Dolce \& Gabbana. (2016, October 15). Fall Winter 2016/2017 Collection. Retrieved from http://www.dolcegabbana.com/woman/collection/

Goodman, B., \& Collins, L. (2013, March 6). John Ruskin and the Arts and Crafts Movement. Retrieved from http://www.arts-and-craftsstyle.com/John-Ruskin.html

Harris, S. (2013, September 16). Christopher Kane Spring/Summer 2014 Ready-To-Wear show report. British Vogue. Retrieved from http://www.vogue.co.uk/shows/spring-summer-2014-ready-towear/christopher-kane/

Hewison, R. (1976). John Ruskin: The Argument of the Eye. London: Thames and Hudson. 
History of wedding dresses. (2013, January 18). Retrieved from https://www.marryjim.com/en/page/show/id/30/template/history

Hortus Eystettensis: Red pepper plants [Painting found in British Library, London]. (n.d.). In B. Besler (Author), Hortus Eystettensis. Retrieved from http://www.bl.uk/collection-items/hortus-eystettensis (Original work created in 1613).

Kane, C. (2013). Spring/ Summer 2014 collection [Fashion Show]. Exhibited in London, 16 September 2013.

Knapp, S., Raven, P., Raven, P., \& Magee, J. (2003). Flora: An Artistic Voyage Through the World of Plants. London: Scriptum Editions.

McQueen, A. (2006) Sarabande [Fashion Show]. Exhibited at the Cirque d'Hiver, Paris, 6 October 2006.

McQueen, A. (2015). Savage Beauty [Display]. Exhibited at the Victoria \& Albert Museum, London, 14 March 2015 - 2 August 2016.

Morris, W. (1919). Tulip [Block-Printed Cotton]. In L. Parry, V\&A Pattern William Morris. (p. 9). London: V\&A Publishing.

Naturalism. (2010, February 11). Retrieved from http://savagebeauty.alexandermcqueen.com/naturalism.html Noaleco. (2009, September 1). What is Surface Design? [Web log post]. Retrieved from http://noaleco.com/blog/what-is-surface-design/

Page, O. (Director), \& Geffen, A. (Producer). (2012, May 20). The Making of The Kingdom of Plants [Television series episode]. In The Making of The Kingdom of Plants. London: Sky Atlantic. 
Parry, L. (2009). V\&A Pattern William Morris. London: V\&A Publishing.

Parry, L., MacCarthy, F., Faulkner, P., Harvey, C., Press, J., Salmon, N., ... Watkins, R. (1996). William Morris. London: Philip Wilson Publishers.

Rogers, K. (2016, May 26). Biophilia hypothesis. In Encyclopaedia Britannica online. Retrieved 23 November 2017 from https://www.britannica.com/science/biophilia-hypothesis

Saunders, G. (1995). Picturing Plants: An Analytical History of Botanical Illustration. London: Zwemmer.

Stearn, W.T. (1990). Flower Artists of Kew. London: The Herbert Press.

Wilcox, C.(Ed.) (2015). Alexander McQueen (C. Wilcox, Ed.). London: V\&A Publishing.

The Art League (2015, April 2). What is Surface Design? It's All Around You [Web log interview]. Retrieved from https://www.theartleague.org/blog/2015/04/02/what-is-surface-designits-all-around-you/

The British Library. (2005, April 19). Hortus Eystettensis. Retrieved from http://www.bl.uk/collection-items/hortus-eystettensis

The Garden Museum (2014) Fashion \& Gardens [Display]. Exhibited at the Garden Museum, London, 7 February 2014 - 27 April 2014.

Ulrich, R. (1993). Biophilia, Biophobia, and Natural Landscapes. In S.R. Kellert \& E.O. Wilson (Eds.) The Biophilia Hypothesis. Washington, D.C.: Island Press. Retrieved 23 November 2017 from 
https://www.researchgate.net/publication/284655696_Biophilia_biopho bia_and_natural_landscapes

Urry, A. (2015, June 9). Building on greenbelt land has soared over five years. BBC News. Retrieved from http://www.bbc.co.uk/news/business32998019

Victoria \& Albert Museum. (2005, March 11). The Arts \& Crafts Movement. Retrieved from http://www.vam.ac.uk/content/articles/t/the-arts-andcrafts-movement/

Victoria \& Albert Museum. (2006, April 3). William Morris \& Wallpaper Design. Retrieved from http://www.vam.ac.uk/content/articles/w/william-morrisand-wallpaper-design/

Wilhide, E. (1991). William Morris Decor and Design. London: Pavilion Books Limited.

Woollaston, V. (2013, June 18). America's oldest cave paintings found, dating back Six Thousand Years. Mail Online. Retrieved from http://www.dailymail.co.uk/sciencetech/article-2343766/American-caverock-art-lay-hidden-SIX-THOUSAND-YEARS-offers-uniqueremarkable-insight-Native-American-societies-lived-lives.html

Yukikoandthe. (2012, February 19). Alexander McQueen S/S RTW 2007, Sarabande [Video File]. Retrieved from https://www.youtube.com/watch?v=zC6iza82qi4 